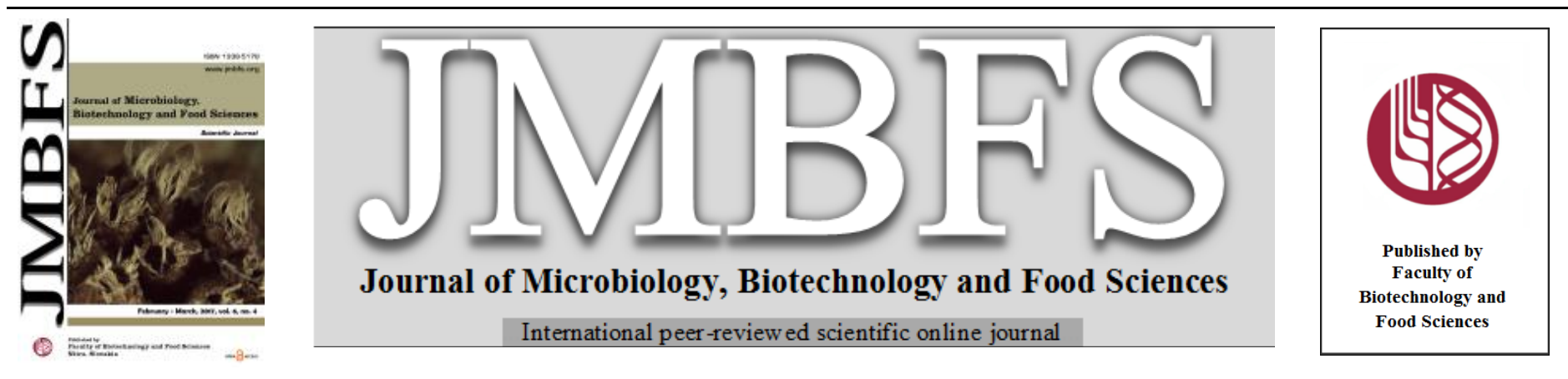

\title{
BIOSCOURING OF WOOL USING PROTEASE FROM BACILLUS SUBTILIS ISOLATED FROM ABATTOIR WASTE
}

\author{
Pallavi Badhe ${ }^{1}$, Manasi Damale ${ }^{2}$ Ravindra Adivarekar ${ }^{1} *$ \\ Address(es): Prof. R.V. Adivarekar, \\ ${ }^{1}$ Department of Fibres and Textile Processing Technology, Institute of Chemical Technology, N.P. Marg, Matunga, Mumbai, 400019, India. \\ ${ }^{2} \mathrm{R}$ and D Manager, Sarex Chemical Pvt. Ltd, Mumbai, India.
}

*Corresponding author: rvadivarekar@ictmumbai.edu.in

doi: 10.15414/jmbfs.2017.6.4.1012-1018

\section{ARTICLE INFO}

Received 6. 1. 2016

Revised 24. 10. 2016

Accepted 21. 11. 2016

Published 1. 2. 2017

Regular article

OPEN $\partial_{\text {ACCESS }}$

\begin{abstract}
Bioscouring refers to the enzymatic removal of impurities from fibres/fabrics, which endows it with improved hydrophilicity for further wet processes. Enzymatic scouring preserves the fibre's structure and strength, avoids high energy consumption and severe pollution problems that are associated with conventional alkaline treatments. In the present study, protease enzyme was extracted from Bacillus subtilis which was isolated from abattoir (slaughter house) waste. Different medium parameters were optimized for maximal enzyme production. The enzyme was partially purified using ammonium sulphate precipitation followed by dialysis bag method. Partially purified protease enzyme was used in the bioscouring of wool fibres. Different parameters such as $\mathrm{pH}$, temperature, time, enzyme concentration were optimized to achieve an efficient scouring. Comparison of enzymatic process for wool fibre with conventional alkaline soap process in terms of weight loss, whiteness index, tensile strength and FTIR studies confirmed that bioscouring could be as effective as the conventional process.
\end{abstract}

\section{INTRODUCTION}

Wool is a natural protein fibre which is obtained from sheep skin. Raw wool fibers obtained from the sheep contain greasy substances referred to as impurities, as high as $40-50 \%$. Sabaceous glands of sheep's skin secretes oils and fats, often referred to as wool fat/grease, essentially a mixture of higher fatty alcohols and acids (Saravanan et al., 2014). The contaminants consist of 5-25\% grease, $2-15 \%$ suint and 5-20\% dirt, moisture, vegetable matter, sand and dirt. All these impurities tend to make the raw wool highly hydrophobic; which has to be removed to make it hydrophilic prior to its further processing. However, entire removal of wool wax is not desirable at fibre stage, in order to facilitate the lubricating actions among the fibers during subsequent spinning processes. The conventional methods of wool scouring utilize high amount of chemicals, detergent, alkali etc which create some serious problems; both, for the environment and the industry while effluent treatment and disposal (Halliday, 2002).

Traditionally, wool scouring is carried out by using alkali and soap at temperature $60^{\circ} \mathrm{C}-80^{\circ} \mathrm{C}$. The alkaline scouring treatment emulsifies the waxes and breaks down peptide bonds into water-soluble or water-emulsifiable products that are later washed off from the wool materials. This process effectively removes all impurities that exist in the raw wool fibres but has a high energy requirement and the effluent is ecologically undesirable because of its high alkalinity, biochemical and chemical oxygen demand. These drawbacks in the process led to a consideration of alternatives. Bioscouring of wool with suitable enzymes appears to be most promising in this respect. The necessity to use more environmental friendly processes leads to the replacement of conventional chemicals by enzymatic ones. Bioscouring is a novel process based on the idea of particularly targeting fats, waxes, suints, dirt etc. with specific enzymes.

Zheng et. al have reported a method to optimize the wool-scouring process with bio-enzymes of Bacillus Subtilis and Candida lipolytica. (Zheng et. al., 2012). Enzymatic treatment of textiles has been of great interest because of its effectiveness under mild treatment conditions (Cardamone et al., 2006). Enzymes act in the $\mathrm{pH}$ range between 5 and 8 , at temperatures around 30 to $40^{\circ} \mathrm{C}$ at atmospheric pressure while conventional method requires $\mathrm{pH} 10.8$ at temperature around $60^{\circ} \mathrm{C}-80^{\circ} \mathrm{C}$. These treatments also enhance many textile properties such as wettability, dye uptake and polymer adhesion (Negri $\boldsymbol{e t}$ al., 1993; Brack et al., 1999).
From an environmental point of view, enzymes are active in small doses and highly biodegradable; hence, the use of enzymes in scouring helps in reduction of the auxiliary agents, which usually are poorly biodegradable.

As per the literature, various enzymes like protease, lipase, pectinase and amylase have been used to carry out treatments on wool (Saravanan et al., 2014; Sayad et al., 2010; Hmidet et al., 2009).

Proteases or proteinases are proteolytic enzymes which catalyze the hydrolysis of proteins. Based upon their structures or properties of the active site, there are several kinds of proteases such as serine, metallo, carboxyl, acidic, neutral and alkaline proteases. Proteases are industrially important enzymes and constitute a quarter of the total global enzyme production (Kalaiarasi and Sunitha, 2009) Proteases are industrially important due to their wide applications in leather processing, detergent industry, food industries, pharmaceutical, textile industry etc (Deng et al., 2010; Jellouli et al., 2009).

Commercially in wool industry, protease enzyme is used due to its substrate specificity. This enzyme tends to remove desired impurities like wax, suint, sand and vegetable matter etc. from raw wool fibre to make it hydrophilic. Effective removal of wax from raw wool substrate with the enzyme under mild conditions will provide high quality of wool for the subsequent dyeing and finishing processes with less energy consumption under safer conditions. In contrast to drastic alkaline conditions conventionally used, treatment with protein degrading enzymes would not affect the internal structure of wool fibre and thus avoid fibre damage. Wide scale industrial application of protease requires their cost effective production to make the process economically viable (Shukla, 2001; Karmarkar 1999).

Pre-treatment of wool fiber with enzyme leads to increase its hydrophilicity with enhanced swelling properties. Protease can catalyse the degradation of different component of wool fibre (Hooda 2013). Protease enzyme penetrates into amorphous region and causes swelling and it leads to changes in the disulphide region of cystine than amide components during chemical degradation. ((L. Ammayappan 2013).

In the present investigation, a successful attempt has been made for production of protease using submerged fermentation $(\mathrm{SmF})$ from a newly isolated strain of Bacillus subtilis from degraded slaughter house waste material and its application in the bioscouring of wool fibre in textile industry. The parameters essential for effective wool scouring like time, temperature, $\mathrm{pH}$, enzyme concentration, etc were optimized. 


\section{MATERIAL AND METHODS}

\section{Raw Materials}

The raw greasy merino wool fibres of Australian origin were procured from (WRA) Wool Research Association, Thane, Mumbai, India for the scouring experiments being difficult to scour as they contain the high amount of contaminants such as wool wax, dirt, dust and suint. Protease enzyme used for bioscouring was extracted from $B$. subtilis obtained from abattoir waste at our laboratory. Identification of the bacteria was carried out by $16 \mathrm{~S}$ rRNA sequencing method. Casein was purchased from Sigma Chemicals. Chemicals for microbiological experiments were supplied by Himedia, Mumbai and all other chemicals were procured from S.D. Fine chemicals, Mumbai.

\section{Microorganism and enzyme production}

The B. subtilis used in this study was isolated from degraded abattoir (slaughter house waste), collected from local market, Mumbai, India. For production of protease enzyme, $100 \mathrm{ml}$ of nutrient medium containing $1 \%$ gelatin $\mathrm{w} / \mathrm{v}$ (as protein source), $0.5 \%$ yeast extract and $100 \mathrm{ml}$ distilled water at $\mathrm{pH} 14$ was inoculated with $1 \%$ inoculums of $24 \mathrm{~h}$ old B. subtilis culture $\left(1 \times 10^{8} \mathrm{CFU} / \mathrm{ml}\right)$ As reported earlier, Bacillus species has optimum temperature of $40^{\circ} \mathrm{C}$ for its growth and its matabolic activity is at highest peak during its growth phase due to which the enzyme works efficently (Badhe et. al 2016). The flasks were incubated at $40^{\circ} \mathrm{C}$ for $24 \mathrm{~h}$ on a rotary shaker maintained at $150 \mathrm{rpm}$. After $24 \mathrm{~h}$ the broth was centrifuged at $5000 \mathrm{rpm}$ at $4^{\circ} \mathrm{C}$ for $20 \mathrm{~min}$ and the cell free supernatant was collected. The supernatant was used as crude enzyme extract. The application of enzyme in the textile industry does not require high grade purity for enzymes and generally requires use of the crude or the partially purified enzyme preparation (Nerurkar et. al 2013). Thus, partial purification of the protease was carried out by ammonium sulphate precipitation since ammonium sulphate is highly soluble in water, cheap, and has no deleterious effect on the structure of protein. Ammonium sulphate was added to the crude enzyme sample to get $30 \%$ saturation and was kept overnight at $4^{\circ} \mathrm{C}$. It was then centrifuged at $6000 \mathrm{rpm}$ for $20 \mathrm{~min}$. The precipitate was suspended in phosphate buffer, $\mathrm{pH} 7.0$ and was dialyzed against the same buffer to carry out desalting process.

\section{Protease assay}

Protease activity was measured by caseinolytic method, (Walter, 1984). One unit of enzyme was defined as the amount of enzyme that liberates peptide fragments equivalent to $1 \mathrm{mg}$ of bovine serum albumin (BSA) under the assay conditions.

\section{Conventional scouring}

Conventional scouring was carried out at $\mathrm{pH} 10$ for $2 \mathrm{~h}$ at $35^{\circ} \mathrm{C}$ to $40^{\circ} \mathrm{C}$. The solution used for scouring contained $2 \mathrm{~g} / \mathrm{L}$ Auxipon NP solution (non-ionic surfactant) and $3 \mathrm{~g} / \mathrm{L}$ sodium carbonate solution (alkali). MLR was kept at 1:30 Sample was given hot wash. The fibres were firstly air dried and then conditioned at $20 \pm 1{ }^{\circ} \mathrm{C}$ and $65 \pm 2 \% \mathrm{RH}$ for at least $24 \mathrm{~h}$ in desiccator containing calcium chloride.

\section{Bioscouring}

Different parameters of bioscouring namely buffer $\mathrm{pH}$, enzyme concentration, temperature and time period were optimized to examine the efficiency of protease from B.subtilis and to further obtain efficient removal of impurities. The raw wool fibres were subjected to four different treatment solutions stated below:

1. Phosphate buffer at $\mathrm{pH} 7.0$ and enzyme $(\mathrm{B}+\mathrm{E})$

2. Phosphate buffer, soap and enzyme $(B+S+E)$

3. Phosphate buffer, alkali and enzyme $(\mathrm{B}+\mathrm{A}+\mathrm{E})$

4. Phosphate buffer, soap, alkali and enzyme $(B+S+A+E)$

The raw wool fibre samples were subsequently suspended in buffer of $\mathrm{pH}$ ranging from 3.0 to 11.0 . The material to liquor ratio was set at 1:30 with varying dosage of protease in the range of $2 \%$ to $14 \%$ on the weight of fabric for treatment time of $30,60,90,120,150$ and $180 \mathrm{~min}$ at different temperatures ranging from $30{ }^{\circ} \mathrm{C}$ to $80{ }^{\circ} \mathrm{C}$. The bioscouring process optimization was carried out by varying one parameter at a time, keeping other factors constant. The experiments were performed in the water bath (Bio Technics India). After the enzymatic treatment; the fibres were given hot wash at boiling temperature for 30 min, air dried and dried in desiccator for $24 \mathrm{~h}$.

Efficiency of bioscouring for each parameter was evaluated by monitoring weight loss of the fibres as the difference before and after the bioscouring treatment Wool sample, bioscoured using protease enzyme under optimized parameters, was used for further analysis.

\section{Evaluation of fibre properties}

\section{Weight loss determination}

Enzyme-treated and untreated wool fibers were conditioned at $20 \pm 1{ }^{\circ} \mathrm{C}$ and $65 \pm$ $2 \% \mathrm{RH}$ for at least $24 \mathrm{~h}$ before being weighed. Weight loss was expressed as:

Weight loss $\%=\frac{\mathrm{W} 1-\mathrm{W} 2}{\mathrm{~W} 1} \times 100$

Where, $W_{1}$ is the conditioned weight of the sample before enzymatic treatment, and $\mathrm{W} 2$ is the conditioned weight of the sample after enzymatic treatment respectively.

\section{Wettability (Drop test)}

The wettability of raw wool and enzyme treated wool fibres was measured using standard test, BS 4554:1970. According to the method, the time (sec) required by a drop of water to be absorbed by the fibre is defined as the ability of the fibre to get wet.

\section{Sinking time}

Sinking time test AATCC 17-2005 was modified for being used for fibre. Instead of fabric, a bundle of fires was used as indicative test for evaluating absorbency.

\section{Alkali solubility}

To quantify the damage to the epicuticle of wool, alkali solubility in terms of weight loss of raw wool and enzyme treated fibres was measured using IWTOTM-4-00 standard test method. The values were calculated as a percentage of the original mass, according to the equation given below,

$$
\text { Alkali solubility }(\%)=\frac{M 1-M 2}{M 1} \times 100
$$

Where, M1 is the mass of oven dry sample before sodium hydroxide treatment, and $\mathrm{M} 2$ is the mass of oven dry sample after sodium hydroxide treatment.

\section{Residual grease content}

Efficiency of removal of grease content of conventional scoured and enzyme scoured wool sample was evaluated by using the following formula according to standard method IWTO1903:

$$
\text { Grease Content }=\frac{\mathrm{W} 1-\mathrm{W} 2}{\mathrm{~W} 1} \times 100
$$

Where, W1 is the weight before removal of grease from wool sample and W2 is the weight after removal of grease from wool sample.

\section{Determination of Moisture Regain}

Moisture regain was calculated using the following equation according to ASTM method 2654-76:

$$
\text { Moisture regain }(\%)=\frac{\mathrm{W} 1-\mathrm{W} 2}{\mathrm{~W} 2} \times 100
$$

Where, W1 is the weight of the conditioned sample at standard humidity and W2 is the weight of the sample dried to constant weight.

\section{Determination of Moisture Content}

The samples were preconditioned in a desiccator for $24 \mathrm{hr}$ at $65 \pm 2 \% \mathrm{RH}$ and 27 $\pm 2^{\circ} \mathrm{C}$. The moisture content was determined after obtaining the weight of wool dried at $105^{\circ} \mathrm{C}$ for $3 \mathrm{hr}$. The oven dry mass was determined according to standard IWTO-34-85-E method.

$$
\text { Moisture Content }(\%)=\frac{W 1-W 2}{W 1} \times 100
$$

Where, $\mathrm{W}_{1}$ is the weight of the conditioned sample at standard RT and temperature and $\mathrm{W}_{2}$ is the weight of the sample dried to constant weight.

\section{Single Fiber Strength Test}

The single fiber strength of raw and scoured wool was measured on Universal Tensile Machine supplied by Aimil Limited, Navi Mumbai according to ASTM D 3822 standard test method. The instrument was based on constant rate of 
elongation (CRE) principle. The distance between jaws was $10 \mathrm{~mm}$ and the travel rate was $6 \mathrm{~mm} / \mathrm{min}$.

\section{Fiber Mean Diameter Test}

Fiber diameter measurement was carried out using OFDA 100 as per the standard IWTO472011. The fiber samples were cut into $2 \mathrm{~mm}$ snippets and spread on a 70 mm square glass slide. The whole slide was scanned with a minimum of 6000 fibers. For each sample, three measurements were taken. The mean diameter and standard deviation of the sample were then calculated.

\section{Whiteness \& Yellowness measurement}

The ASTM whiteness Index (WI) and yellowness Index (YI) of samples, before and after scouring were determined by using Computer Colour Matching (CCM) System (Spectrascan5100+) according to IWTO3503 standard test method. The Improvement in whiteness and reduction in yellowness are expressed as the percentage change relatively to the original whiteness and yellowness respectively.

\section{FTIR analysis}

FTIR study was carried out to analyze the changes in structural groups and impurities on the wool surface of raw wool and enzyme treated wool fibres.

\section{SEM}

The surface morphologies of the wool samples were visualized using a JSM 6380L, an analytical scanning electron microscope (JEOL Company, Japan), operated at a typical accelerating voltage of $5 \mathrm{kV}$. The samples were sputtercoated with Platinum for $30 \mathrm{~s}$ at $15 \mathrm{~mA}$ prior to the observation.

\section{Statistical Analysis}

All the experiments were conducted in triplicate and results were expressed as mean \pm standard deviation. Student's t-test was used to analyze data, and statistical significance was declared at $\mathrm{p}<0.05$.

\section{RESULTS AND DISCUSSION}

\section{Protease production in submerged fermentation}

Glucose was used as sole carbon source for protease production using B. subtilis in submerged fermentation. Gelatin was used as protein source as a substrate Protease so produced showed maximum protease activity of $63 \mathrm{U} / \mathrm{ml}$ after optimizing various physical, chemical parameters of fermentation and partial purification using Ammonium sulphate.

\section{Bioscouring}

Raw wool fibres were subjected to four different treatment solutions as reported above. It was seen from (Figure.1) that there was maximum weight loss and a less than $2 \mathrm{sec}$ wetting time when raw wool was treated with the solution containing buffer and enzyme $(B+E)$. Solution $B+E$ was found to be optimum and was used for further studies, due to that protease enzyme is stable in buffer solution (Joshi et al. 2013).

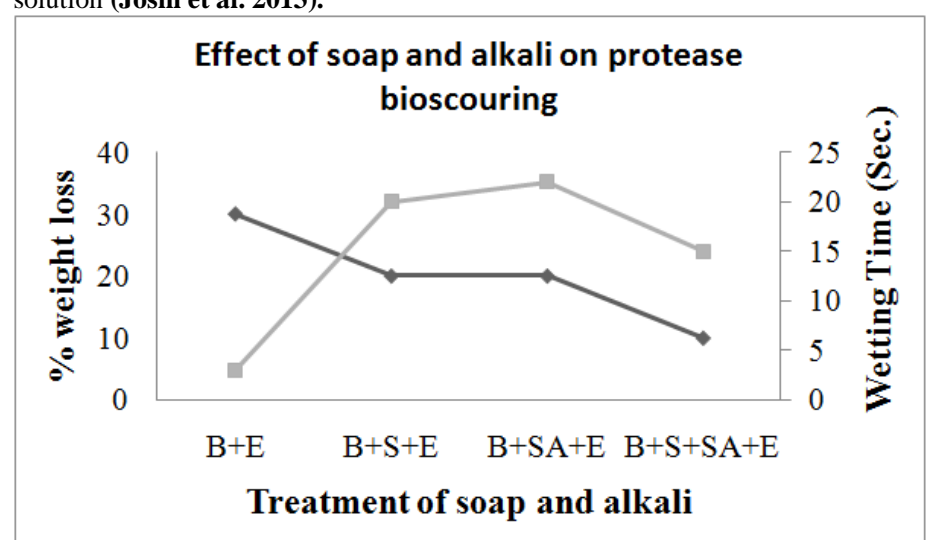

Figure 1 Effect of four different treatment solutions on protease bioscouring. Protease scouring was carried out at protease dose of $2 \%$ (owf), $\mathrm{pH} \mathrm{7.0,} \mathrm{at} 40^{\circ} \mathrm{C}$ keeping MLR at 1:30. Filled squares indicate percentage weight loss of the wool fibre and filled diamonds indicate wetting time of wool fibres in second. Four different treatment solutions: solution B+E containing $50 \mathrm{mM}$ phosphate buffer and enzyme, solution $\mathrm{B}+\mathrm{S}+\mathrm{E}$ containing buffer, soap and enzyme, solution $\mathrm{B}+\mathrm{A}+\mathrm{E}$ containing buffer, alkali and enzyme, solution $\mathrm{B}+\mathrm{S}+\mathrm{A}+\mathrm{E}$ containing buffer, soap, alkali and enzyme.
In order to explore the potential of our protease enzyme in bioscouring of wool, various factors like $\mathrm{pH}$, enzyme concentration, temperature and time period were optimized. As seen from (Figures. 2-5), the optimal conditions for the bioscouring of wool sample were $4 \%$ protease dosage on the weight of the fibre at $60{ }^{\circ} \mathrm{C}$, Phosphate buffer $\mathrm{pH} 7.0$ and a treatment time of $120 \mathrm{~min}$.

\section{Effect of Time period}

Effective bioscouring using protease was optimized for $120 \mathrm{~min}$ in terms of weight loss and wettability. From the (Figure.2), it can be seen that the weight loss remained steady upto $60 \mathrm{~min}$, after that there was a steep rise and the maximum weight loss was observed at $120 \mathrm{~min}$. After that there was a sudden decline in weight loss which can be attributed to protein specific action of protease such that within treatment time of $120 \mathrm{~min}$ itself, protein and hence the other loosened impurities get removed.

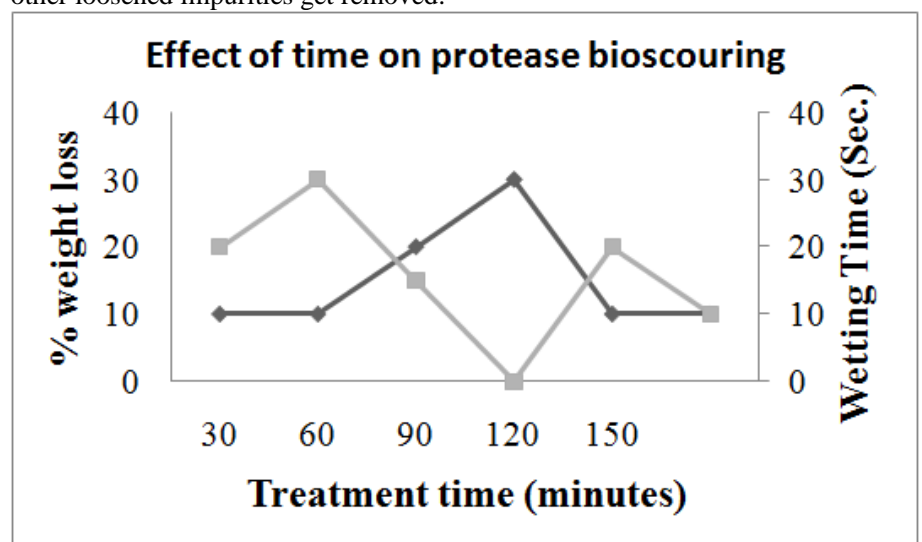

Figure 2 Effect of time period on protease bioscouring.

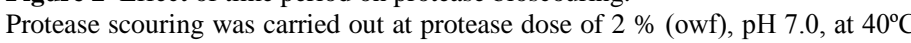
for varying period of time keeping MLR at 1:30. Filled squares indicate percentage weight loss of the wool fibre and filled diamonds indicate wetting time of wool fibres in second.

\section{Effect of temperature}

Effect of temperature on protease scouring can be seen from (Figure. 3). As compared to $20 \%$ weight loss obtained in alkaline scouring, sufficient weight loss is achieved when scouring is carried out between temperature ranges of $30^{\circ} \mathrm{C}$ and $80^{\circ} \mathrm{C}$, where as scouring efficiency decreases drastically as temperature of scouring bath is raised to $80^{\circ} \mathrm{C}$. This is because the protease enzyme must be showing less activity at $80^{\circ} \mathrm{C}$ as compared to lower temperatures mentioned earlier. Optimum temperature for scouring of wool using protease was observed as $60^{\circ} \mathrm{C}$

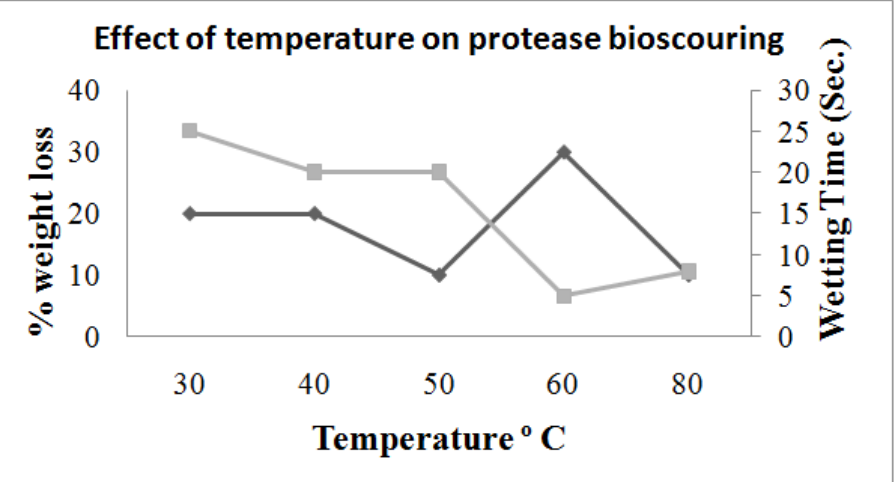

Figure 3 Effect of temperature on protease bioscouring.

Protease scouring was carried out at protease dose of $10 \%$ (owf), $\mathrm{pH} 7.0$ for $120 \mathrm{~min}$ at various temperatures keeping MLR at 1:30. Filled squares indicate percentage weight loss of the wool fibre and filled diamonds indicate wetting time of wool fibres in second.

\section{Effect of enzyme concentration}

As can be seen from (Figure. 4), $4 \%$ of protease enzyme (owf) is optimum for scouring as further increase in the protease concentration showed more or less similar weight loss as compared to weight loss achieved when $4 \%$ of protease enzyme was used for scouring. 


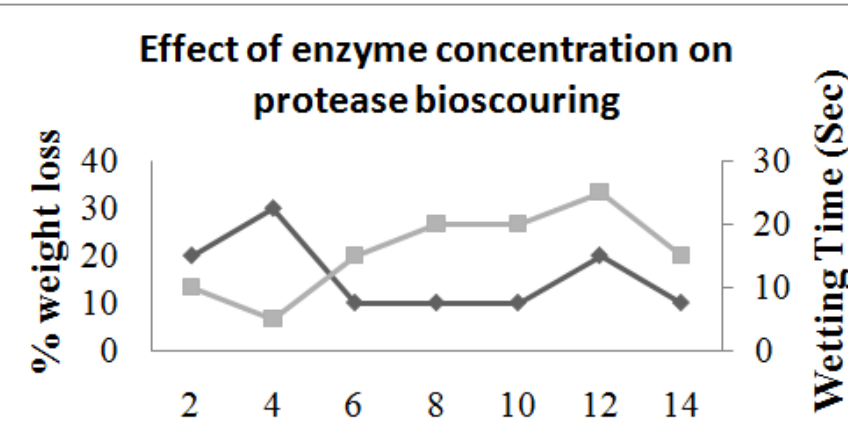

Enzyme concentartion (\%)

Figure 4 Effect enzyme concentration on protease bioscouring.

Protease scouring was carried out at $\mathrm{pH} 7.0,40^{\circ} \mathrm{C}$ for $120 \mathrm{~min}$ at various concentration of the protease keeping MLR at 1:30. Filled squares indicate percentage weight loss of the wool fibre and filled diamonds indicate wetting time of wool fibres in second.

\section{Effect of pH}

As can be observed from (Figure.5), $\mathrm{pH}$ of scouring bath greatly affects scouring action of the protease enzyme. Optimum $\mathrm{pH}$ for scouring of wool using protease was observed as 7.0 .

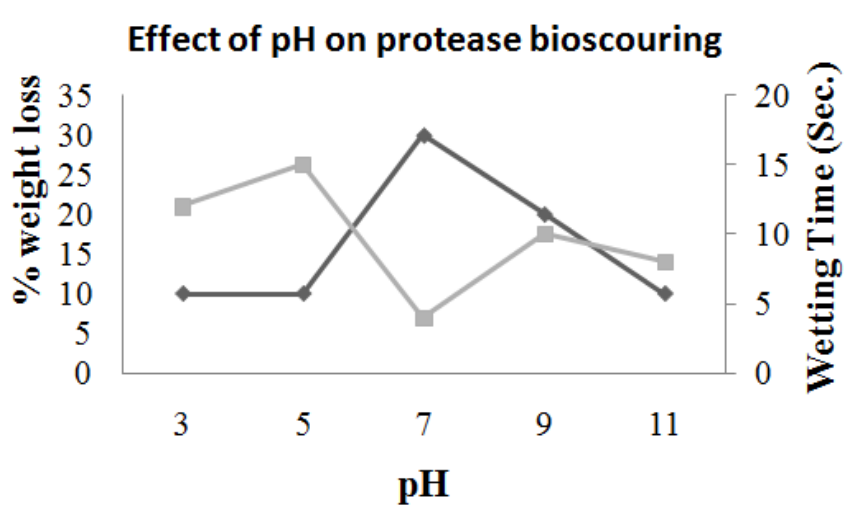

Figure 5 Effect of $\mathrm{pH}$ on protease bioscouring.

Protease scouring was carried out at protease dose of $10 \%$ (owf), $\mathrm{pH} 7.0$ for 120 $\min$ at $60^{\circ} \mathrm{C}$ for varying $\mathrm{pH}$, keeping MLR at 1:30. Filled squares indicate percentage weight loss of the wool fibre and filled diamonds indicate wetting time of wool fibres in second.

\section{Wettability of fibre}

The raw wool fibers were tested for wetting time after it was subjected to scouring. The comparison of wetting time for $\mathrm{B}+\mathrm{E}$ solution, conventional i.e. $\mathrm{B}+\mathrm{S}+\mathrm{A}+\mathrm{E}$ solution and raw wool fibers. It was found that after treating raw wool with $\mathrm{B}+\mathrm{E}$ solution, there is increase in its hydrophilicity and wettability was found to be less than $2 \mathrm{~s}$. The raw wool fibres were not able to absorb the water droplet; it was observed that, after more than $30 \mathrm{~min}$ also the water drops remain as it is and can be rolled off easily from the fiber surface without wetting the surface.

\section{Sinking time}

Sinking time of both, conventionally scoured and protease scoured wool sample was found to be less than $2 \mathrm{~s}$. Optimum temperature for bioscouring was found to be $60^{\circ} \mathrm{C}$. At this temperature, though some of the fats or waxes from wool fibre get loosened up, it still adheres to the fibre surface. When hot wash is given, they leach out completely in the bath; allowing the fibre to sink analogous to alkaline scoured fibre.

\section{Alkali solubility}

The alkali solubility of the enzyme treated fibers was tested and compared with the raw wool fibres. The alkali solubility values for wool fibres reported in literature are between 9\% and 15\% for undamaged wool (Atav and Yurdakul, 2011). The alkali solubility for raw wool and enzyme treated wool was found to be $9.10 \%$ and $11.48 \%$.

\section{Residual grease content}

Efficiency of removal of grease content of raw wool which was $11.90 \%$ for conventional scoured, $(\mathrm{B}+\mathrm{S}+\mathrm{A}+\mathrm{E})$ scoured was $0.16 \%$ and enzyme scoured $(\mathrm{B}+\mathrm{E})$ wool sample was $0.36 \%$.

\section{Moisture Regain and moisture content}

Removal of hydrophobic greasy substances from the surfaces of the raw wool is expected to increase the moisture regain values and higher weight loss in the scouring treatment translates to higher moisture regain values. The highest moisture regain values were observed in the case of enzyme scoured i.e. B+E samples at $42.85 \%$, while the moisture regain values of conventional i.e. $\mathrm{B}+\mathrm{S}+\mathrm{A}+\mathrm{E}$ scoured, $\mathrm{B}+\mathrm{S}+\mathrm{E}$ scoured samples, or $\mathrm{B}+\mathrm{A}+\mathrm{E}$ scoured wool samples were in the range of $25 \%$. According to standard method, enzyme and buffer showed maximum moisture regain and content as compared to other.

\section{Effect on Physical properties}

\section{Fiber Mean Diameter Test and Single Fiber Strength Test}

There was no significant effect on mechanical properties of wool fibers on bioscouring. Little difference in the tenacity and elongation of wool fibers is attributing of high degree of variability in fiber dimension and non uniformity in wool. It has also been found that there is no difference in fiber diameter of all the samples as shown in (Table. 1). The fiber diameter ranges between 19.2-19.5 micron (Table. 2) (Kalantzi et al., 2008).

Table 1 Effect of Protease and alkaline scouring on tensile strength of wool fibers

\begin{tabular}{lccc}
\hline Serial no. & Sample & Breaking strength & $\begin{array}{c}\text { Extension } \\
(\boldsymbol{\%})\end{array}$ \\
\hline 1 & Raw wool & 5.80 & 27 \\
\hline 2 & $\begin{array}{c}\text { Alkaline scouring } \\
(\mathrm{B}+\mathrm{S}+\mathrm{A}+\mathrm{E})\end{array}$ & 6.00 & 37 \\
\hline 3 & Protease Scouring (B+E) & 4.10 & 38 \\
\hline 4 & $\mathrm{~B}+\mathrm{S}+\mathrm{E}$ & 5.30 & 34 \\
\hline 5 & $\mathrm{~B}+\mathrm{A}+\mathrm{E}$ & 4.80 & 35 \\
\hline 6 & $\mathrm{~B}+\mathrm{S}+\mathrm{A}+\mathrm{E}$ & 4.10 & 50 \\
\hline
\end{tabular}

Table 2 Effect of protease scouring on the properties of wool fiber

\begin{tabular}{lllll}
\hline Sr. & Fibre & Raw & Alkaline & $\begin{array}{l}\text { Protease } \\
\text { no }\end{array}$ \\
sample & wool & $\begin{array}{l}\text { scoured } \\
(B+A+S+E)\end{array}$ & $\begin{array}{l}\text { Scoured } \\
(B+E)\end{array}$
\end{tabular}

$(\mathbf{B}+\mathbf{S}+\mathbf{E})$

$(\mathbf{B}+\mathbf{A}+\mathbf{E})$

$(\mathbf{B}+\mathbf{S}+\mathbf{A}$

\begin{tabular}{llllllll}
\hline 1 & $\begin{array}{l}\text { Average } \\
\text { fibre } \\
\text { fineness } \\
\text { (micron) } \\
\text { (IWTO }\end{array}$ & 19.3 & 19.2 & 19.2 & 19.2 & 19.2 & 19.2 \\
& & & & & & \\
\hline 2 & SD & 1.13 & 1.27 & 1.59 & 1.11 & 1.33 & 1.46 \\
\hline 3 & CV\% & 21 & 31 & 27 & 26 & 22 & 30 \\
\hline
\end{tabular}

SD- Standard Deviation, CV- Coefficient Variation.

\section{Effect on Whiteness and Yellowness}

Enzymatic removal of wool impurities by the process of bioscouring resulted in whiteness improvement. Though, compared to alkaline scouring yellowness index of the bioscoured wool was less, whiteness index of both alkaline $(\mathrm{B}+\mathrm{S}+\mathrm{A}+\mathrm{E})$ scoured and protease $(\mathrm{B}+\mathrm{E})$ scoured wool was almost similar (Table. 3). Protease being substrate specific, it only attacks peptide bonds and does not remove colouring matter in wool whereas caustic soda removes colouring matter being non-specific in action.

\begin{tabular}{lllll}
\multicolumn{5}{l}{ Table $\mathbf{3}$ Wool fiber properties at different stages of textile wet processing } \\
\hline Serial no. & Fibre sample & WI & YI & BI \\
\hline 1 & Raw wool & 8.71 & 10.31 & 38.51 \\
\hline 2 & Alkaline scouring & 21.29 & 20.46 & 49.57 \\
\hline 3 & $\begin{array}{l}\text { Protease } \\
\text { Scouring (B+E) }\end{array}$ & 20.76 & 11.37 & 48.27 \\
& & & & \\
\hline 4 & B+S+E & 12.19 & 16.96 & 50.96 \\
\hline 5 & B+A+E & 16.29 & 15.56 & 52.43 \\
\hline
\end{tabular}




\begin{tabular}{lllll}
\hline 6 & $\mathrm{~B}+\mathrm{S}+\mathrm{A}+\mathrm{E}$ & 17.21 & 14.31 & 48.01
\end{tabular}

$\mathrm{B}=$ Buffer, $\mathrm{S}=$ Soap, $\mathrm{A}=$ Alkali (sodium carbonate), $\mathrm{E}=$ Enzyme, WI- whiteness index, YIyellowness index, BI- brightness index.

\section{FTIR Spectroscopic Analysis}

The FTIR spectra of the raw wool, alkaline-scoured, protease-scoured fibers were shown in (Figure. 6 to 10) indicating characteristic absorption bands assigned mainly to the peptide bonds $(\mathrm{CONH})$ which represent the fundamental structural unit of the polypeptide chain (Zoccola et al., 2009). The results confirm that no new chemical bonds are produced in wool fibre. The two sharp peaks in the range of 2935-2915/2865-2845 $\mathrm{cm}^{-1}$ for raw wool fibre samples corresponds to Methylene C-H asymmetric/symmetric stretch and similarly at $1485-1445 \mathrm{~cm}^{-1}$ for Methylene $\mathrm{C}-\mathrm{H}$ bend (Meyers, 2000). Intensity of these peaks in raw wool fibre is high, while after protease treatment the intensity of all these peaks (Methylene C-H stretch and bend) reduces, indicating the removal of 18-MEA acid covalently bonded to epicuticle. The peak at $1737 \mathrm{~cm}^{-1}$ for raw wool fibre corresponds to covalent bond of 18-MEA acid to epicuticle through the $(\mathrm{C}=\mathrm{O})$ sulfoester. After B+E solution (protease) treatment, this bond breaks and it can be seen from Fig.7 that, peak at $1737 \mathrm{~cm}^{-1}$ disappears. The five spectra reveal that the bands near $1600 \mathrm{~cm}^{-1}$ assigned to amide I and II vibrations are shifted. They reveal a combination of amide $\mathrm{C}=\mathrm{O}$ and $\mathrm{N}-\mathrm{H}$ modes. The frequency is sensitive to protein conformation, i.e., alpha helix, random, beta-sheet, etc. The intensity is proportional to the concentration of amide linkage, i.e.,-C $(=\mathrm{O})-\mathrm{N}(-\mathrm{H})-$. Yet in this case, it is suspected that the differences are ascribed to the differences in the water content of fibers. There is an H-O-H bending mode at $1635 \mathrm{~cm}^{-1}$. This is supposed to push up the intensity of the amide I peak after B+E solution (protease) treatment (Mori and Inagaki, 2006). After protease treatment the additional peak appears at $1076 \mathrm{~cm}^{-1}$ which corresponds to the S-S oxidation in the surface of wool after treatment (Meyers, 2000; Hocker, 2002).

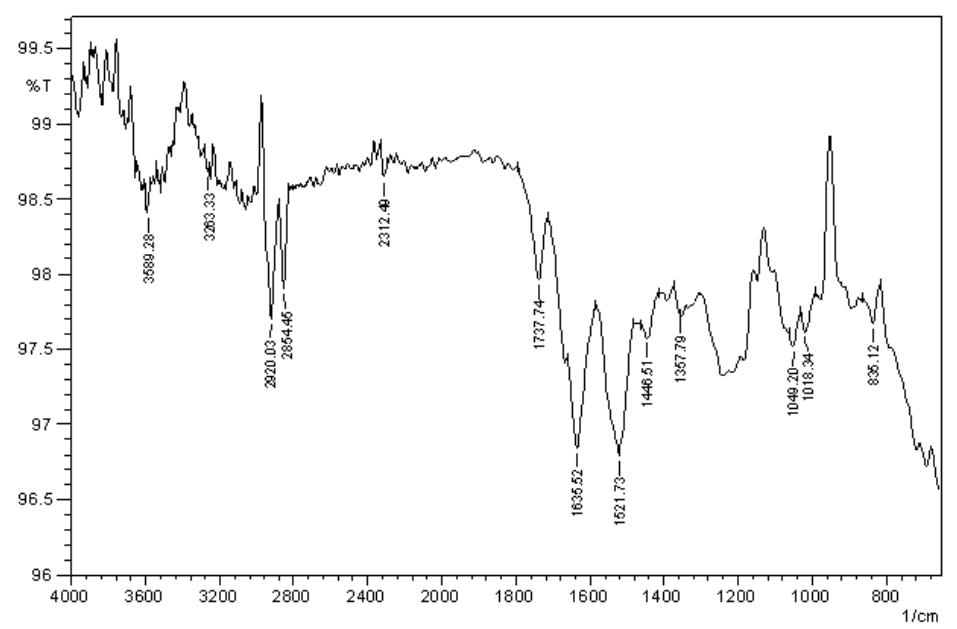

Figure 6 FTIR spectra of raw wool fibre

Analysis of functional group of raw wool fibre at wavelength ranging from 750 $\mathrm{cm}^{-1}$ to $3600 \mathrm{~cm}^{-1}$.

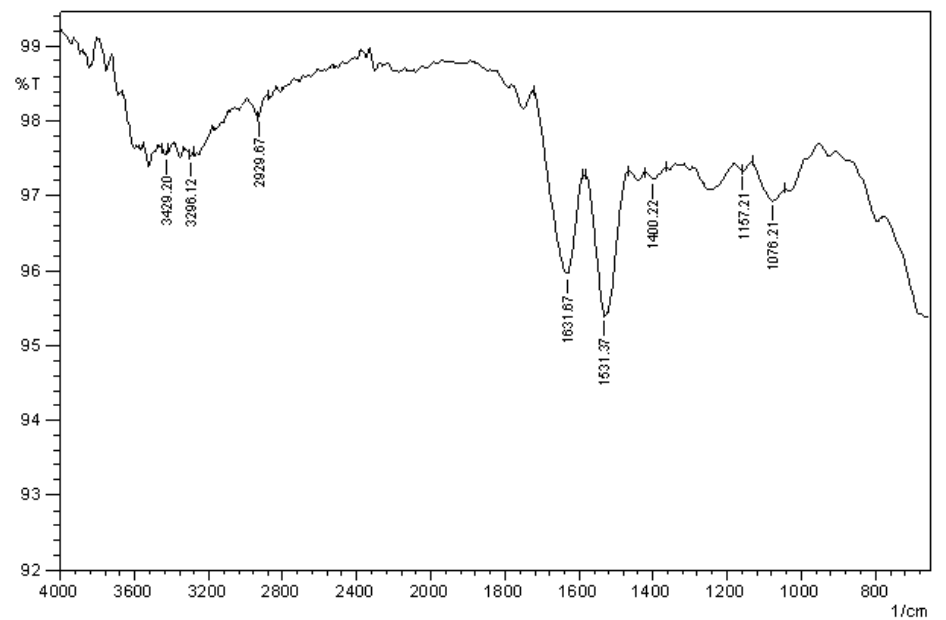

Figure 7 FTIR spectra of protease scoured $(B+E)$ wool fibre.

Analysis of functional group of protease scoured wool fibre at wavelength ranging from $750 \mathrm{~cm}^{-1}$ to $3600 \mathrm{~cm}^{-1}$.

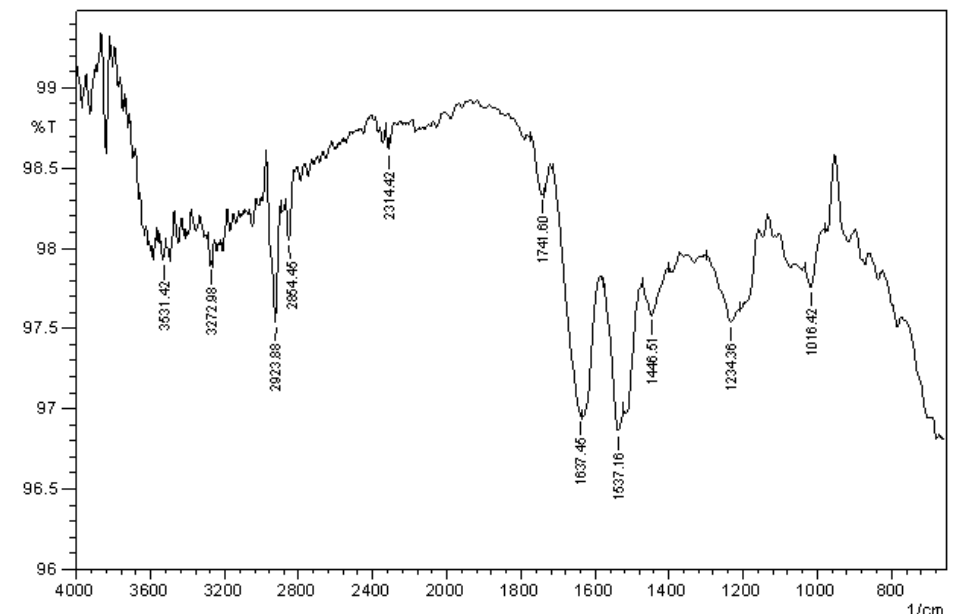

Figure 8 FTIR spectra of buffer, soap, soda ash and enzyme $(B+S+S+E)$ scoured wool fibre.

Analysis of functional group of $\mathrm{B}+\mathrm{S}+\mathrm{S}+\mathrm{E}$ scoured wool fibre at wavelength ranging from $750 \mathrm{~cm}^{-1}$ to $3600 \mathrm{~cm}^{-1}$.

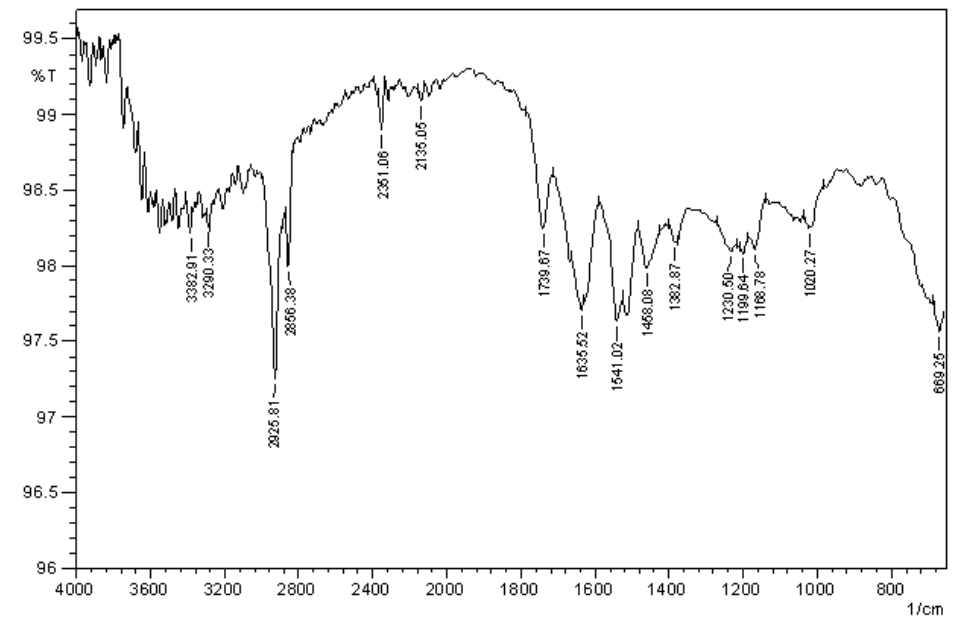

Figure 9 FTIR spectra of buffer, soda ash and enzyme $(B+S+A+E)$ scoured wool fibre.

Analysis of functional group of $\mathrm{B}+\mathrm{S}+\mathrm{A}+\mathrm{E}$ scoured wool fibre at wavelength ranging from $750 \mathrm{~cm}^{-1}$ to $3600 \mathrm{~cm}^{-1}$.

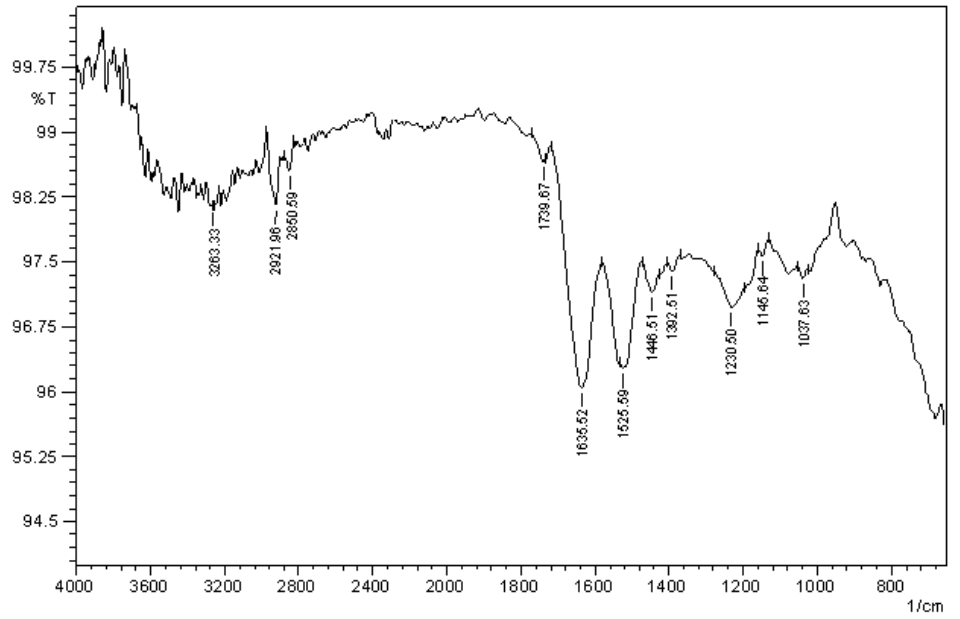

Figure 10 FTIR spectra of buffer, soap and enzyme $(B+S+E)$ scoured wool fibre. Analysis of functional group of $\mathrm{B}+\mathrm{S}+\mathrm{E}$ scoured wool fibre at wavelength ranging from $750 \mathrm{~cm}^{-1}$ to $3600 \mathrm{~cm}^{-1}$

\section{SEM ANALYSIS}

The clarity of wool surface was observed with scanning electronic microscope (SEM), as shown in (Figures 11 to 15 ). It could be seen that, the wool surface scoured using protease enzyme $(\mathrm{B}+\mathrm{E}$ solution) was very clean and smooth as compared with those scoured using conventional process, $\mathrm{B}+\mathrm{S}+\mathrm{E}$ solution, $\mathrm{B}+\mathrm{A}+\mathrm{E}$ solution and $\mathrm{B}+\mathrm{S}+\mathrm{A}+\mathrm{E}$ solution. There was partial removal of cuticles 
from wool fibre due to substrate specificity of protease enzyme. Prominent scales were observed on wool fibre surface when treated with $\mathrm{B}+\mathrm{E}$, as it got damaged with protease enzyme treatment. There was though a rise in surface performance and capillarity effect of wool fiber under this bio-scouring.

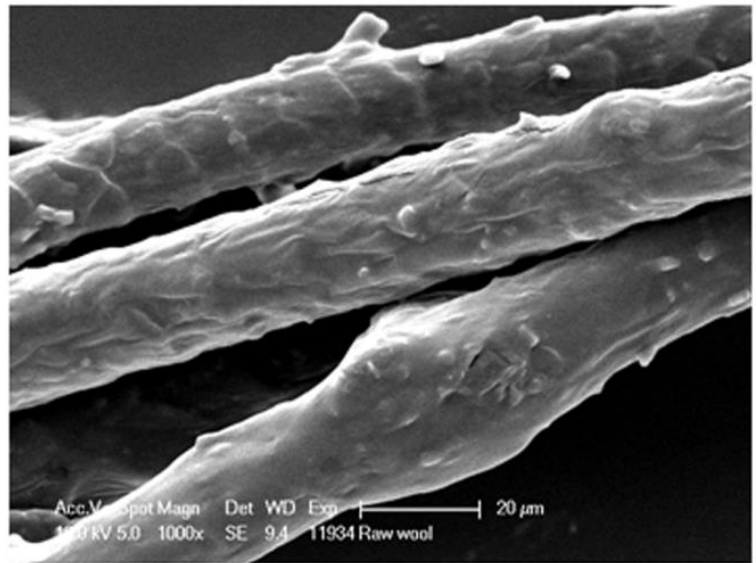

Figure 11 SEM images of raw wool fibre (1000x). Surface analysis of raw wool fibre.

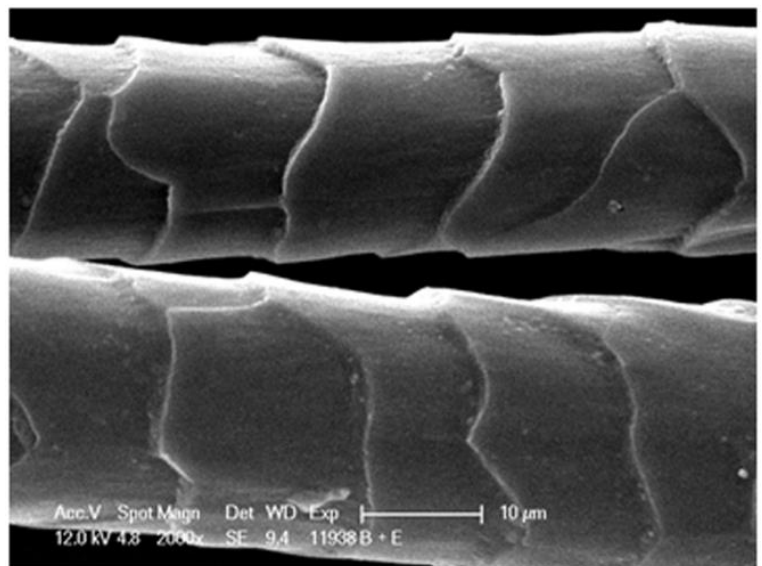

Figure 12 SEM images of protease (B+E) scoured wool fibre (2000x). Surface analysis of protease $(\mathrm{B}+\mathrm{E})$ scoured wool fibre.

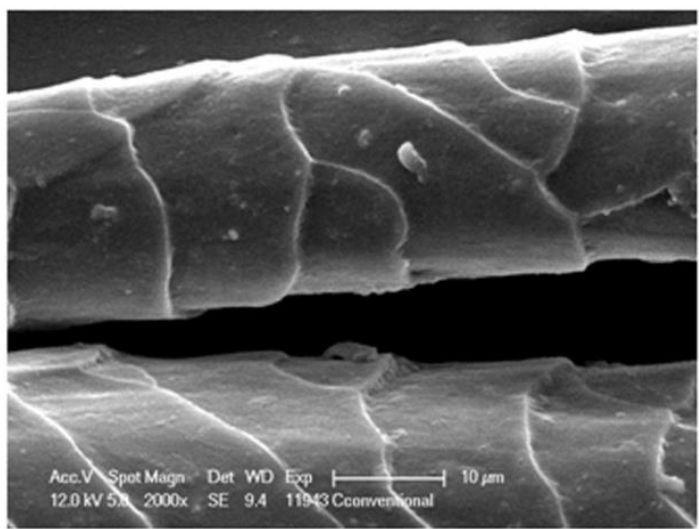

Figure 13 SEM images of alkaline $(B+A+S+E)$ scoured wool fibre (2000x). Surface analysis of alkaline $(B+A+S+E)$ scoured wool fibre.

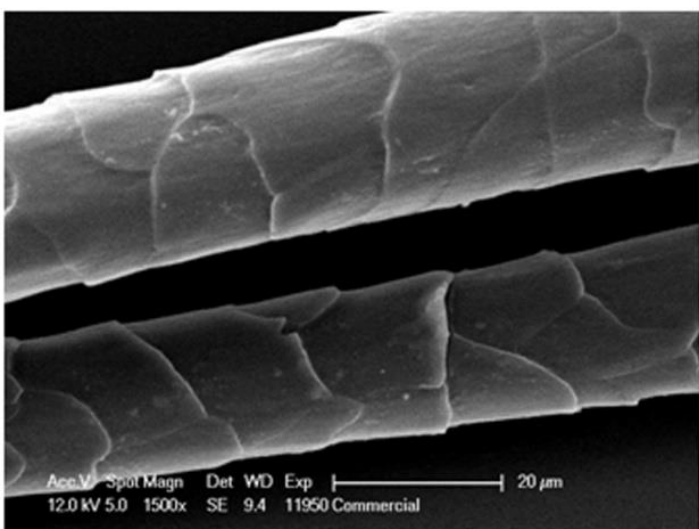

Figure 14 SEM images of commercial scoured wool fibre (1500x). Surface analysis of commercial scoured wool fibre.

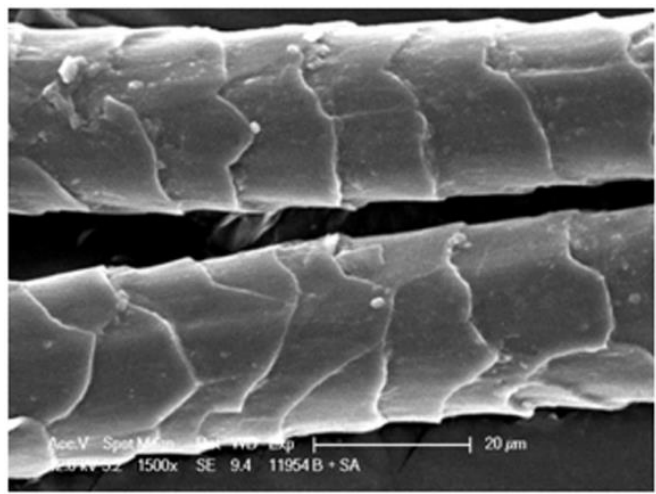

Figure 15 SEM images of $B+A+E$ scoured wool fibre (1500x). Surface analysis of $\mathrm{B}+\mathrm{A}+\mathrm{E}$ scoured wool fibre.

\section{CONCLUSION}

The bioscouring studies indicated that protease from B. subtilis is capable of removing waxes from the raw wool fibre and impart hydrophilicity to the fibre In addition, the experimantal studies of bioscouring parameters clearly states that under alkaline conditions at $60^{\circ} \mathrm{C}$ for $120 \mathrm{~min}$ with a protease dosage of $10 \%$ on the weight of fibre, better than required hydrophilicity is achieved. The sharp peaks obtained from the FTIR data and smooth surface of wool revealed by the SEM images show the efficiency of protease in the removal of waxes from wool fibre indicating no damage to the wool fibre. Thus, the protease is a potential candidate to be used in bioscouring of wool. The approach described in the present work seems to be convincingly reproducible and environment friendly which can be easily adapted by the textile industry. The further work can be undertaken to check dyability of such bioscoured wool fibers vis-a vis conventionally scoured wool and also combine bioscoring and dyeing to acheive shortening of overall processing cycle for dyed wool.

Acknowledgments: The authors gratefully acknowledge UGC-SAP for fellowship and contingency.

\section{REFERENCES}

ATAV, R., YURDAKUL, A. ( 2011). Low temperature dyeing of plasma treated Luxury fibers Part I: Results for Mohair ( Angora Goat). Fibres \& Textiles in Eastern Europe, 19, 2(85), 84-89.

AMMAYAPPAN, L., (2013). Eco- friendly surface modification of wool for its improved functionality: An overview, Asian Journal of Textile", 3(1): 15- 28. http://dx.doi= ajt. 2013.15.28

BADHE, P., JOSHI, M., ADIVAREKAR, R. (2016) Optimized production of extracellular proteases by Bacillus subtilis from degraded abattoir waste, J BioSci. Biotechnol, 5(1): 29-36.

BRACK, N., LAMB, R., PHAM, D., TURNER, P. (1999). Nonionic surfactants and the wool fibre surface. Colloids and Surfaces. A Physicochemical and Engineering Aspects, 146 (11), 405-415. http://dx.doi.org/ 10.1016/S0927-7757(98)00863-2

CARDAMONE, J. M., RICHARD, A. N., DUDLEY, R. (2006). Activated peroxide for enzymatic control of wool shrinkage Part 1: Eiucidation. Textile Research Journal, 76(2), 99-108.

DENG, A., WU, J., ZHANG, Y., ZHANG, G., WEN, T. (2010). Purification and characterization of a surfactant-stable high-alkaline protease from Bacillus sp. B001. Bioresourse Technology, 101, 7100-7116. http://dx.doi.org/10.1016/j.biortech.2010.03.130 
HALLIDAY, L., A. (2002). Wool Scouring, Carbonizing and Effluent treatment in wool": Science and Technology edited by W S Simpson and Crawshaw, G. H. Woodhead Publishing Limited, Cambridge, p. 21-57.

HMIDET, N., ALI, N. E. H., HADDAR, A., KANOUN, S., ALYA, S. K., NASRI, M. (2009). Alkaline proteases and thermostable -amylase co-produced by Bacillus licheniformis NH1: Characterization and potential application as detergent additive. Journal of Biochemical Engineering, 47, 71-79.

http://dx.doi.org/10.1016/j.bej.2009.07.005

HOCKER, H. (2002). Plasma treatment of textile fibers. Pure Applied Chemistry, $74,423-427$.

HOODA, S., KHAMBRA, K., YADAV, N., SIKKA, V. K., (2013) Antimicrobial activity of herbal treated wool fabric, American International Journal of Research in Formal, Applied \& Natural Sciences, 3(1), 66-69.

JELLOULI, K., BOUGATEF, A., MANNI, L., AGREBI, R., SIALA, R., YOUNES, I., NASRI, M. (2009). Molecular and biochemical characterization of an extracellular serine-protease from Vibrio metschnikovii J1. Indian Journal of Microbiology and Biotechnology, 36(7), 939-948.

http://dx.doi.org/10.1007/s10295-009-0572-5.

JOSHI, M., NERURKAR, M., BADHE, P., ADIVAREKAR, R, (2013). Scouring of cotton using marine pectinase, Journal of Molecular Catalysis B Enzymatic 98, 106- 113.

http://dx.doi.org/10.1016/j.molcatb.2013.10.010

KALAIARASI, K., SUNITHA, P.U. (2009). Optimization of alkaline protease production from Pseudomonas fluorescens isolated from meat waste contaminated soil. African Journal of Biotechnology, 8(24), 7035-7041.

KARMARKAR, S. R. (1999). Application of Enzyme on woolen products for its value addition: An overview. Chemical Technology in the pre- treatment processes of textiles, Elsevier Publication., London, p. 418-440.

KALANTZI, S., MAMMA, D., CHRISTAKOPOULOS, P., KEKOS, D (2008). Effect of pectate lyase bioscouring on physical chemical and low-stress mechanical properties of cotton fabrics. Journal of Bioresourse Technology, 99(17), $8185-8192$.

http://dx.doi.org/10.1016/j.biortech.2008.03.020

MEYERS, R. A., JOHN, WILEY \& SONS LTD. ( 2000). Journal of Coates, Encyclopedia of Analytical Chemistry Chichester, p. 10815.

MORI, M., INAGAKI, N. (2006). Relationship between antifelting properties of wool fibers treated with Ar- plasma. Textile Research Journal. 76(89) , 687694.

http://dx.doi.org/10.1177/0040517506065590

NEGRI, A. P., CORNELL, H. J., RIVETT, D. E. (1993). A model for the surface of keratin fibers, Textile Research Journal. 63(2), 109-115.

http://dx.doi.org/10.1177/004051759306300207

NERURKAR, M., JOSHI M., PARITI, S., ADIVAREKAR, R. (2013). Application of Lipase from Marine Bacteria Bacillus sonorensis as an Additive in Detregent Formulation. Journal of Surfactant and Detergency, 16, 435-443.

http://dx.doi.org/ 10.1007/s11743-012-1434-0

SARAVANAN, D., ANUSUYA, C. A., DIVYA, B. B., USHA, M. (2014).

Environmentally Benign Scouring of Wool Fibers Using Mesophile Acidic Lipase. Fibers and Polymers.15(9), 1902-1907.

http://dx.doi.org/10.1007/s12221-014-1902-4

SAYAD, H. E., GABRY, L. E., KANTOUCH, F. ( 2010). Effect of biocarbonization of coarse wool on its dyeability, Indian Journal of Fibre \& Textile Research. 35, 330-336.

SHUKLA, S. R. (2001). Enviroment friendly processing of protein fibers. Indian Journal of fibres \& Textile Research. 26, 116-124.

WALTER, H. E. (1984). Proteinases: Methods with Hemoglobin, Casein and Azocoll as Substrates. In: Methods of Enzymatic Analysis, BERGMEYER. H.U., BERMEYER, J. (Eds.), Wiley, New York, USA, 5, p. 270-274.

ZOCCOLA, M., ALUIGI, A., TONIN, C. (2009). Characterisation of keratin biomass from butchery and wool industry wastes, Journal of Molecular Structure. 938(1), 35-40.

http://dx.doi.org/10.1016/j.molstruc.2009.08.036

ZHENG, L., DU, BING., WANG, LILI., (2012). Bio-scouring process optimization of wool fiber and wastewater utilization, The Journal of the Textile Institute, 103(2), 159-165. 